\title{
CHRONIC KIDNEY DISEASE OF UNKNOWN AETIOLOGY OF SRI LANKA IN HUMAN RIGHT PERSPECTIVE: WITH SPECIAL REFERENCE TO NATIONAL AND INTERNATIONAL HUMAN RIGHTS REGIME
}

\author{
A. H. Wijayath*
}

Attorney-at-Law, Sri Lanka

\begin{abstract}
Chronic Kidney Disease of Unknown Aetiology (CKDu) is a condition that the reduction of the kidney functions over a period of time. CKDu has affected the dry zone in Sri Lanka and last few decades the use of agro-chemicals rising up in these areas due to large-scale cultivation of paddy crop. The researchers revealed that the accumulation of heavy metals as agro-chemical residues in water resources is one of the major environmental factors affect the CKDu. At present, United Nations recognizes the right to access clean water as a human right, even though the people of dry zone unable to enjoy the right due to pollution of their water resources by agro-chemical residues. Further, their right to life, right to a healthy environment and the right to engage in lawful occupation also violate due to this disease. The main purpose of this research is to identify the international and national human right provisions relate to CKDu in Sri Lanka. This research mainly explores the contribution of national and international jurisdiction to eradicate or minimize the outbreak of CKDu from Sri Lanka while ensuring the fundamental rights of citizens.
\end{abstract}

Keywords-Chronic Kidney Disease of Unknown Aetiology, Fundamental Rights, Constitution of Sri Lanka, International Human Right Law

\section{Introduction}

The Chronic Kidney Disease of Unknown Aetiology (CKDu) is prevalence in major paddy cultivation areas in the dry zone of Sri Lanka. The disease was identified in mid-1990 and it was not found in Sri Lanka about 30 years ago. The number of affected patients rapidly increases from the year 2000 and disease is limited only to specific geographical areas such as Medawachchiya and Padaviya in the Anuradhapura District, Medirigiriya and Hingurakgoda in the Polonnaruwa District Nickawewa in the Kurunegala District and Girandurukotte in the Badulla District. According to the Ministry of Health in the year 2014, there were 69,258 CKDu cases reported in Sri Lanka and estimated death toll is $20,000 .{ }^{1}$ All the CKDu affected patients are paddy farmers and the majority are males.

The CKDu is a disease which reports from agricultural lands in worldwide. In 1950 a kidney disease was identified in the Balkan region of Europe and still, its aetiology is unknown. El Salvador and Nicaragua of Central America, El Minima in Upper Egypt, Andhra Pradesh and Odisha in South India are the areas which affected CKDu. ${ }^{2}$.

\footnotetext{
${ }^{1}$ Jayasumana.C, et al "Glyphosate, Hard Water, and Nephrotoxic Metals: Are They the Culprit Behind the Epidemic of Chronic Kidney Disease of Unknown Aetiology in Sri Lanka?", International Journal of Environmental Research and Public Health, 11 (2014) 2125-2147.

2 Lunyera, J., et al, 2015 ' CKD of Uncertain Aetiology: A Systematic Review', CJASN ePress.
}

Corresponding Author Email:* arunihemanthi85@gmail.com 


\section{What is CKDu?}

Chronic Kidney Disease (CKD) is defined as "any condition which is reduced kidney functions over a period of time”. CKD is common among the Diabetics, Glomerulitis ${ }^{3}$ and Hypertension ${ }^{4}$ patients.

$\mathrm{CKDu}$ is a disease which is reduced the kidney functions over a period of time due to unidentified factors and normally the condition is progressive without showing symptoms. In Sri Lanka, the healthy paddy farmers around 40-70 years of age affected by CKDu. CKDu prevalent area covers 17,000 sq. $\mathrm{km}$ in the dry zone and around 2.5 million people (1/8 population in Sri Lanka) are affected. ${ }^{5}$

The kidney is the pair of bean shape organ situated at the back abdomen below the diaphragm which responsible for excretion of nitrogenous waste from the blood. These waste mainly comprised of Urea excreted with Urine from the human body. The kidney tolerates the fluid level of the body which responsible for the blood pressure level of the body also. When someone is suffering from $\mathrm{CKDu}$, the purification mechanism in blood is decreased and the nitrogenous waste level of blood is gradually increased. Due to the excessive amount of Urea and other nitrogenous waste accumulated in blood ${ }^{6}$ may result in nausea, lethargy, drowsiness and if untreated eventually death. As the treatment, the patient needs to transplant the kidneys or should undergo Haemodialysis ${ }^{7}$. These therapeutic methods are highly cost-effective.

According to the report issued by Ministry of Health Sri Lanka, the early stages of CKDu patients do not show any symptoms and rapidly their kidney damage over three or more months, making diagnosis and treatment difficult. Nearly $80 \%$ of patients experience total kidney failure within two years following diagnosis, therefore, it is difficult to diagnose the disease in early stages and give the treatment to the appropriate time. ${ }^{8}$

\section{Risk factors of CKDu}

In between years of 1965-1980 the agricultural colonies ${ }^{9}$ were established in the dry zone especially in Polonnaruwa district based on the Mahaweli Development project ${ }^{10}$. Further ancient irrigation systems such as Nuwara wewa (Nuwara Tank), Kala wewa (Kala Tank), Parakrama Samudraya supply water to agricultural lands and daily usage for people through a lake system in the dry zone. The farmers cultivate paddy on a large scale by using the water resources and to enhance the harvest they happen to use agrochemicals such as pesticides, weedicides and fertilizers. After 1970 agrochemicals were heavily used for farmlands in Sri Lanka. In between the year, 1970 to 1995 usage of pesticides increased by almost 110 times $^{11}$. As a result of that, the residues of these agrochemicals, the heavy metals and other compounds accumulated in the soil and especially in water resources. Through the food chains and water resources, these residues are accumulated in the human body in high percentages. According to the investigations, the drinking water resources contain elevated

\footnotetext{
${ }^{3}$ Any type of kidney disease involving with glomeruli(the network of blood capillaries contained in the kidneys)

${ }^{4}$ High Blood Pressure

${ }^{5}$ Chandrajith.r at el 2010, Natural Radionuclides and trace elements in rice field soil in relation to fertilizer application, Study in a Chronic Kidney Diseases area in Sri Lanka, Environmental Earth Sciences,60,193-201

6 , This condition is called as Uraemia in medicine (Oxford Concise Colour Medical Dictionary, $3^{\text {rd }}$ Edition, Oxford Press)

${ }^{7}$ A technique of removing waste material from the blood

${ }^{8}$ Ministry of Healthcare and Nutrition, Epidemiology Unit, Sri Lanka and the World Health Organization.2009

${ }^{9}$ A mass project initiated by the Government of Sri Lanka to establish agricultural lands in dry zone for the landless and unemployed citizen.

${ }^{10}$. Large scale Irrigation project initiated in 1961 to generate hydroelectric power and supply water to dry zone cultivation in Sri Lanka

11 Wilson, C., 1998. "Cost and Policy Implications of Agricultural Pollution with special Reference to Pesticides". PhD Thesis, Department of economics,

University of St Andrews, Scotland, U.K.
} 
Cadmium, Lead and Arsenic level in the dry zone. ${ }^{12}$ Through these studies, it is revealed that these heavy metals are the residues of the agrochemicals.

Further, the natural water resources in dry zone contained elevated salt levels such as Fluoride and Magnesium. Therefore, naturally, the water in the dry zone is hard water. Another plenty of researches revealed that the hard water also another risk factor of CKDu. ${ }^{13}$.A research conducted by the University of Peradeniya identified that the toxins from Cyanobacteria ${ }^{14}$ also considered as another risk factor of $\mathrm{CKDu}$ which are growing in water reservoirs and canals ${ }^{15}$. Besides, low water consumption by the farmers who are exposing the heavy sunlight for a longer period is considered as another risk factor.

\section{Background of CKDu and Human Rights}

At present $\mathrm{CKDu}$ is becoming a major health problem in Sri Lankan context. Through this work, it tries to identify the human right perspective of CKDu. The Constitution of Sri Lanka codified and implemented a set of human rights named as fundamental rights and these rights pave the path to enjoy the freedom and dignity of citizens of Sri Lanka.

Moreover, Sri Lanka is a signatory to cardinal international human right conventions such as the International Covenant on Civil and Political Rights, International Covenant on Economic, Social and Cultural Rights, and Universal Declaration of Human Rights. As a state party, Sri Lanka is bound to safeguard the rights enunciated by these conventions. Further, this work explores the international human rights instruments which address the CKDu in Sri Lanka.

A plenty of researches could be found in relation with CKDu in Sri Lanka. Majority of them investigated the risk factors and aetiology of $\mathrm{CKDu}$. These works conducted as scientific researches and researchers explored the major cause or causes of CKDu. A considerable number of researchers discussed the sociological impact of $\mathrm{CKDu}$. Majority of them tried to find the economic, and social background of CKDu victims and their families. Geographical researches also conducted to determine the nexus between geographical factors and CKDu in Sri Lanka as this condition limited only to certain areas. Some works discussed the health impact, and social impact of CKDu even though, researches regarding the human right perspective of CKDu is a dearth.

The legal impact of $\mathrm{CKDu}$ is another significant area to research as Sri Lanka does not address the CKDu in relation to the law. Due to the lack of legal researches, the legal impact of CKDu is unclear. The relationship between the human right violation and CKDu cannot be ascertained due to the lack of researches in the human rights arena. Moreover without having actual and proper data regarding the legal aspect of CKDu the legal drafters and legislator cannot get a clear idea to amend, draft and introduce new laws to justice system of Sri Lanka which address the CKDu issues. Therefore legal researches should be conducted progressively to explore the area of CKDu.

\section{Research Statement}

The CKDu is becoming a lamentable problem among Sri Lankan farmers and prevalence of the disease is growing rapidly. But unfortunately Justice system of Sri Lanka unable to procure sufficient legal protection to

\footnotetext{
${ }^{12}$ Chandrajith, R, et al 2011 'Chronic kidney diseases of uncertain aetiology ( CKDu) in Sri Lanka: Geographic Distribution and environmental implications', Environmental Geochemistry and Health, 33,pp.267-278

13 Jayasumana, C.at el (2013) P. Glyphosate, Hard Water and Nephrotoxic Metals: Are They the Culprits Behind the Epidemic of Chronic Kidney Disease of Unknown Aetiology in Sri Lanka?' International Journal of Environ Research and Public health. Feb; 11(2), pp. 2125-2147

${ }^{14}$ A type of microorganism live in water and manufacture their own food by using sunlight and Carbon Dioxide

15 Jayasinghe. T,2011, Chronic Kidney Disease, Risk Factors Identification Secondary Data Analysis
} 
the affected victims and the human rights regime incapable to intervene to this major human right violation in a considerable manner while comparing with other jurisdictions.

Sri Lanka is one of the forward countries in South Asia which tries to adopt international human rights concepts to domestic jurisdiction while ratifying a number of international conventions and treaties, although these international instruments incapable to perform their role to address the CKDu and its bad consequences in the human right angle.

\section{Research Objectives}

-To analyze existing National and International Human Rights provisions which address CKDu

-To examine the contribution of Human Rights Law and other Domestic Laws in order to protect the present and future generation from $\mathrm{CKDu}$

-To suggest possible legal recommendation to eradicate CKDu from Sri Lanka

\section{Research Methodology}

\section{Methods}

The normative method is used to complete the work and mainly based on documentary analysis through the internet in a qualitative manner.

Through documentary research method, the researcher plans to analyses and investigate the internet based documents which are contained the information on CKDu and Human Rights.

The normative method target not only to gather data relating to CKDu and Human Rights but also to point out in which respects the objects of the research could be improved through recommendations.

\section{Sources}

As the primary source the Constitution of Sri Lanka, Universal Declaration on Human Rights (UDHR), International Covenant on Civil and Political Rights (ICCPR), International Covenant on Economic, Social and Cultural Rights (ICESCR) will be critically evaluated through this work in order to examine the nexus between Human Rights and CKDu.

The Constitution of Sri Lanka is the supremacy domestic law and major human rights provisions are contained in it. Further, other international covenants are treated as cardinal human right treaties which are ratified by Sri Lanka and without analyzing these treaties any single study regarding international human right law is becoming useless.

Scholarly articles, newspaper articles, research data gathered through the internet, law journal and official reports will be explored as secondary sources.

\section{Materials}

The internet-based articles relating to CKDu and Human Rights up to the month of September 2018 were downloaded from the search engine "Google" and used "CKDu in Sri Lanka, Human Rights and Pesticides" as keywords. 


\section{Analysis method}

The constant comparative method is used as the data analysis method, where the findings are compared with existing findings.

\section{Limitations}

Methodological limitations-Although this study focused on the CKDu affected victims and their rights it was not conducted direct interviews with victims and other resource persons such as Human Rights activists and legal experts due to the technical and practical difficulties, therefore, it is limited only to internet-based articles and journals.

A few numbers of domestic and international legislations which are very common to human rights law are analyzed in relation to CKDu due to the limitations of words.

The geographical limitations-This article discusses the CKDu victims of a limited geographical area in Sri Lanka as almost all prior studies regarding CKDu limited only to such areas and CKDu is prevalence in those areas.

\section{Limitations of the researcher}

Access- While collecting documents from the internet, a large number of documents were freely available even though a few numbers of important studies were not freely available. Therefore the access to important articles was obstructed.

Duration of time-The researcher had a limited period of time to collect and study the prior works as the researcher should adhere to the time schedule.

Language problem-A few numbers of internet-based articles published in the Sinhala language. While the translation process the actual expression may be subjected to vary as the researcher did not use a professional translator to this process.

\section{Discussion}

Under this section, two aspects regarding the human right perspective of CKDu will be discussed.

From the first part, the Constitution of Sri Lanka may be critically evaluated with relates to CKDu issues. Further, decided judgments on environmental issues which relates to fundamental rights may be analyzed in order to understand the nexus between human rights and CKDu.

In the latter part, the international human rights conventions and treaties which ratified by Sri Lanka will be discussed comprehensively to examine the contribution of international human rights law to safeguard the present and future generation from $\mathrm{CKDu}$ and redress the harm to the affected communities. Further, contemporary developments of human rights law in the globe which could be applied to the CKDu and related matters will be retrieved.

\section{Fundamental Rights and CKDu in Sri Lanka}

The Constitution of Sri Lanka which was consolidated in the year 1978 codified a specific chapter from article 10 to 14 , includes "fundamental rights". 


\section{Right to Life}

The Constitution of Sri Lanka does not expressly declare the right to life as a fundamental right. Even though, the Supreme Court of Sri Lanka is interpreting the fundamental rights provisions in a creative manner to protect the right of citizens through the judgments. A landmark judgment Sriyani Silva V Iddamalgoda ${ }^{16}$ changed the entire human rights arena in Sri Lanka. While delivering the judgment the question raised whether the article 11 includes, by implication, the right to life. The article 11 contains the right to free from torture ${ }^{17}$. In his judgment Fernando J held that; "I hold that Article 11 (read with Article 13(4)) ${ }^{18}$, recognizes a right not to deprive of life whether by way of punishment or otherwise - and, by necessary implication, a right to life". Therefore it could be assumed that the right to life is recognized through the judgments as a fundamental right in Sri Lanka and it should not be infringed by any circumstances except the court ${ }^{19}$.

The right to life could be treated as the rudimentary human right because, without the right to life, all other rights would be meaningless and useless.

As said earlier, the death toll is 20,000 of affected individuals of CKDu. Further, nearly $80 \%$ of CKDu patients experience total kidney failure within 2 years following diagnosis. ${ }^{20}$ Thereafter their lives depend on the process of dialysis or kidney transplant. According to Handunnetti at el (2012) death becomes inevitable for most patients because of the inadequacy of medical services, costly treatment, such as dialysis and organ transplantation, and the poverty of most victims ${ }^{21}$. While studying these findings it could be clearly identified that the CKDu violates the right to life of affected patients.

\section{Right to a Clean Environment}

Mankind totally depends on the environment. The co-relationship between human beings and the environment cannot be separated. "Environmental degradation has a devastating effect on people's lives. Without a habitual environment, all other human rights become either unattainable or meaningless" 22 Right to a clean environment is not a fundamental right under the constitution of Sri Lanka.

Although the chapter VI of the Constitution contains the directive principles of state policy which are guided the President, Parliament and the Cabinet to establish a just and free society. The article 27(14) under the chapter VI states that "the State shall protect, preserve and improve the environment for the benefit of the community." The article 28 states, "the fundamental duties of every citizen of Sri Lanka which are formulated to enjoy the right and freedom." But unfortunately, this chapter has included major limitations. The article 29 states that these provisions cannot be enforced by any court or tribunal and do not have any legal right or obligation.

\footnotetext{
${ }^{16}$ Sriyani Silva (Wife of Jagath Kumara-Deceased) $v$ Iddamalgoda, Officer-In-Charge, Police Station, Payagala and Others (2003) 1 Sri L R 14

${ }_{17}$ Article 11- No person shall be subjected to torture or to cruel, inhuman or degrading treatment or punishment.

${ }^{18}$ Article 13 (4)- No person shall be punished with death or imprisonment except by order of a competent court, made in accordance with procedure established by law

${ }^{19}$ Sri Lankan Criminal Justice system still imposing capital punishment for a limited number of offences under the penal code of Sri Lanka even though the punishment is not practically activated.

${ }^{20}$ Ministry of Healthcare and Nutrition, Epidemiology Unit, Sri Lanka and World Health Organization, 2009

${ }^{21}$ ibid

${ }^{21}$ Handunnetti, D. \& Daniel, S. 'Conflicting reports highlight scientific data gaps in Sri Lanka's chronic kidney disease', 2012, Sci Dev. Net.

${ }^{22}$ Richard L H, Human Rights and the Environment, Earth right International,1997,p 1
} 
In Sri Lankan judgments such as Bulankulame $v$ The Secretary, Ministry of Industrial Development and Others,(Eppawela case) $)^{23}$, Al Haj Ashik and Others v OIC Weligama Police and 8 Others ${ }^{24}$ the Supreme Court approached to discuss the doctrine of the healthy /clean environment. In Eppawala case Amarasinghe J held that;

"Human beings are at the centre of concerns for sustainable development. They are entitled to a healthy and productive life in harmony with nature (Principle 1, Rio De Janeiro Declaration). "25

Further, he emphasized that;

"Decisions with regard to the nature and scale of activity require the most anxious consideration from the point of view of safeguarding the health and safety of the people, naturally, ensuring the viability of their occupations, and protecting the rights of future generations of Sri Lankans."

Through these facts, it could be understood that the right to a clean environment is safeguarded by the judgments even though, it is not expressly declared by the Constitution of Sri Lanka.

According to the number of researches, one of the main risk factors of CKDu is contaminated soil and water resources in the dry zone. Some recent researches revealed that the close nexus between water and soil pollution and prevalence of CKDu in agricultural areas (Jayasumana at el 2011, Chandrajith at el 2010, Bandarage 2014, WHO 2009). Further, researchers identified that the major factor of soil contamination is agrochemicals. (Chandrajith at el 2010, WHO 2012)

In this respect, it could be identified that the right of the clean and healthy environment is infringed by the agrochemicals and as a bad consequence of agrochemicals, the CKDu is prevalence in the dry zone. Thus the usage of agrochemicals has deprived the right of the healthy environment of the citizens of dry zone.

\section{Right to engage in a lawful occupation}

Under the article 14(1) (g) of the Constitution, engage in lawful occupation is concerned as a fundamental right in Sri Lanka ${ }^{26}$. Through a number of judgments "right to engage in lawful occupation" is emphasized as a fundamental right. In Eppawala Case the petitioners who are paddy /diary and high land farmers in a proposed major mining area alleged that their right to engage in lawful occupation is violated due to this mass project. The Supreme Court accepted their argument and stated that their right should not be violated by the development project.

Through a survey conducted by the Department of Census of Sri Lanka in the year 2012, more than 65\% of citizens are depending on farming or agriculture-based occupations in CKDu affected areas. In his study Ranasinghe M (2017) observed that all most all CKDu affected individuals are in the age range of 40-70 years of age and they are the sole breadwinners of their families. When the sole breadwinners have developed a disease like CKDu they are unable to earn for their dependents. As a result of that, these families are financially destroyed and distressed in many ways. (Bandarage, 2005)

\footnotetext{
23 (2000) 3 SLR 243

24 (2007)XIII Bar Association Law Journal Report, 159

25 (2000) 3 SLR 243, p 247

26 Article 14 (1) (g)-the freedom to engage by himself or in association with others in any lawful occupation, profession, trade, business or enterprise
} 
From the ancient times, the dry zone of Sri Lanka cultivated paddy by using irrigation water. From the kingdom's era farmers of Anuradhapura and Polonnaruwa areas which are situated in dry zone cultivated paddy for the domestic consumption. But unfortunately, at the present, the citizens of the dry zone are in danger due to their traditional occupation of farming as they are becoming a prey of CKDu. Therefore at a glance, article 14 (1) (g) of the constitution is violated due to CKDu prevalence in the dry zone.

\section{International Human Rights Law and CKDu}

Universal Declaration of Human Rights (UDHR)

UDHR is one of the cardinal human rights documents which tries to safeguard the basic rights of mankind around the globe. The document aims to build up a peaceful environment which protects the rule of law and dignity of human beings.

UDHR proclaims the right to life ${ }^{27}$ as a basic human right of every person. Under the international human rights law, the right to life is treated as first generation human rights because it is an incipient right identified in 1948.

Sri Lanka s a signatory to UDHR, therefore, the government of Sri Lanka is binding by the provisions of this document and should take appropriate measures to safeguard the rights enunciated by the UDHR. But unfortunately, the paddy farmers who are affected by CKDu cannot enjoy the right to life because their life is in danger due to the complications of this disease. The CKDu violates the right to life of these innocent farmers. As a state party to UDHR, Sri Lanka unable to take measures to safeguard this right of dry zone citizens.

The article 23(1) of UDHR safeguards the right to work, just and favourable working conditions of work ${ }^{28}$. Under this article, 2 types of major rights are professed. The right to work and the right to enjoy a favourable surrounding while working. The relevancy of the right to a "favourable working condition" to the Sri Lankan context, the farmers have the right to work in a pollution free environment. But unfortunately, in CKDu affected areas the favourable environment is destroyed due to agrochemicals and residues. Further, this article states that "the everyone has free choice of employment" nevertheless the residents of dry zone avert from their traditional occupation due to CKDu risk.

International Covenant on Civil and Political Rights (ICCPR)

Sri Lanka is a signatory to ICCPR, therefore the government has an obligation to protect the rights proclaimed in the covenant. Sri Lanka has adopted the rights enunciated in the covenant to the territorial jurisdiction through Act No 56 of 2007 (ICCPR Act). By introducing the civil and political rights to the Sri Lankan justice system, these rights are becoming a part of domestic law and could be compellable from the domestic courts.

Article 1 of the covenant states that the every human being has a right to freely pursue their economic development ${ }^{29}$. But unfortunately, the CKDu is directly obstructed and limited the economic development of $\mathrm{CKDu}$ patients and their families. As mentioned in a previous chapter almost all CKDu patients are breadwinners of their families and due to the ill -health, they are unable to earn as usual. Therefore, they are incapable to enjoy the right of economic development prescribes in the covenant.

\footnotetext{
${ }^{27}$ Article 3-Everyone has the right to life, liberty and security of person.

${ }^{28}$ Article 23 (1)- Everyone has right to work, to free choice of employment, to just and favourable conditions of work and to protection against unemployment.

${ }^{29}$ Peoples have the right of self-determination. By virtue of that right they freely determine their political status and freely pursue their economic, social and cultural development
} 
Further, article 6 of the covenant states, the right to life of every human being as a civil and political right. As discussed under the topic of UDHR the right to life is deprived by the CKDu. Generally, a disease outbreak cannot treat as a factor of depriving the right to life of human beings even though CKDu is an exception. The $\mathrm{CKDu}$ could be categorized as a man-made disease because of major risk factors of CKDu associates with human activities.

International Covenant on Economic, Social and Cultural Rights (ICESCR)

ICESCR basically targets to develop the family of human beings nourished with economic and social rights. These rights are called the second generation human rights and these are recognized by the governments after the II World War.

The ICESCR does not directly emphasize the right to life even though major economic and social rights which relate to $\mathrm{CKDu}$ is widely accepted. For example, right to a clean and healthy environment which is widely discussed under the topic of CKDu, directly enunciated by article 12 (2) (b) ${ }^{30}$. But unfortunately, Sri Lanka is unable to safeguard the right of the clean and healthy environment, especially in the dry zone. Environmental hygiene is less attainable in this area due to agrochemicals. As a bad consequence of the violation of article 12 (2) (b) the CKDu is frequently afflicted the innocent farmers.

Further, the ICESCR pays attention to the health rights of the people. A number of article of the covenant professes this right through different ways. Article 7 (2) (b) states that the safety and healthy condition while on working. ${ }^{31}$ Further, article 12 discusses the mental and physical health of everyone. The article 12 (2) (b) focuses on the environmental and industrial hygiene and article 12 (2) (c) ${ }^{32}$ considers the prevention of diseases of everyone. Further, the covenant stresses the appropriate state parties to create the condition to assure medical assurance and medical attention in the event of sickness. ${ }^{33}$ As a state party to the covenant, the government of Sri Lanka is bound to protect and should take measures to achieve these rights.

As a developing country, the health service is in a favourable condition in Sri Lanka while compared with other developing countries. But unfortunately, Sri Lanka unable to fulfil the health rights enunciated in ICESCR up to a favourable level. For example, article 7 (2) (b) is a right which discusses the healthy condition while working. In the dry zone the paddy farmers unable to enjoy this right as their working areas such as agricultural lands and water resources polluted by agrochemicals and their residues. Further, environmental and industrial hygiene is in lamentable condition due to the aforementioned reason. The government of Sri Lanka take appropriate actions to protect the rights mentioned in article 12 (2) (c) and (d) by developing the health care system ${ }^{34}$ and allocating budget as CKDu funds ${ }^{35}$. Further, the covenant emphasizes the right to work ${ }^{36}$ and social security ${ }^{37}$ also. But this deleterious illness derogates the rights of patients of CKDu and their families too.

\footnotetext{
${ }^{30}$ Article 12 (2). The steps to be taken by the States Parties to the present Covenant to achieve the full realization of this right shall include those necessary for:(b) The improvement of all aspects of environmental and industrial hygiene

${ }^{31}$ The States Parties to the present Covenant recognize the right of everyone to the enjoyment of just and favourable conditions of work which ensure, in particular:(b) Safe and healthy working conditions;

32 Article 12 (2) (b) The improvement of all aspects of environmental and industrial hygiene;

(c) The prevention, treatment and control of epidemic, endemic, occupational and other diseases;

${ }^{33}$ Article 12 (2) (d) The creation of conditions which would assure to all medical service and medical attention in the event of sickness.

${ }^{34}$ Initiated Special Dialysis units in government hospital at CKDu affected zones and specialized hospital for Kidney related diseases in Colombo

35 The government of Sri Lanka allocated budget of Rs 27.62 billion to fund CKDu initiatives for the period 2016 to 2018

${ }^{36}$ Article 6(1). The States Parties to the present Covenant recognize the right to work, which includes the right of everyone to the opportunity to gain his living by work which he freely chooses or accepts, and will take appropriate steps to safeguard this right.
} 
Resolution 64/292-The Human Right to Water and Sanitation

In the United Nations General Assembly dated $28^{\text {th }}$ July 2010 passed the resolution 64/292 emphasized the access to safe drinking water and sanitation as a human right. The resolution requests from developed countries and organizations to provide financial support and technical assistant to developing countries in order to provide clean, safe, accessible and affordable drinking water and sanitation to all mankind. ${ }^{38}$

Neither the judiciary of Sri Lanka nor the legislature steps forward to declare the access to safe drinking water as a right of the citizens of Sri Lanka. Even though as an active member of United Nations Organization Sri Lanka has an obligation to consider such type of foremost rights which are salient to humankind.

In his work Ranasinghe. M (2017) proclaimed that the heavy metals such as Arsenic, Cadmium, Lead the residues of agrochemicals highly concentrated in water resources in the dry zone. Majority of researches revealed that these heavy metals responsible for the prevalence of CKDu. Therefore it could be assumed that the $\mathrm{CKDu}$ is one of the aftermaths of unclean or polluted drinking water. Therefore the residents of the dry zone cannot enjoy the right to clean water safeguarded by the UN resolution 64/292.

\section{Conclusion and Recommendations}

It could be identified that the fundamental rights of citizens in Sri Lanka, is violated by the CKDu outbreak and the domestic human rights regime incompetent to addresses the issues of $\mathrm{CKDu}$ and it's bad consequences. Because the Constitution of Sri Lanka identified a scanty number of human rights as fundamental rights of the citizens. It contains only the $1^{\text {st }}$ generation and $2^{\text {nd }}$ generation human rights and not even address the momentous rights such as the right to clean water and the right to development which are having a close relationship with the CKDu. Further, the legislature did not put a minute attempt to adopt newly introduced human right concepts to the constitution through Constitutional amendments.

Fortunately, the cardinal international human rights conventions procure a considerable legal protection to the individuals who are affected by CKDu. But Sri Lanka is a Dualist country ${ }^{39}$ therefore through ratification, the treaties are not becoming the part of municipal law in Sri Lanka. After the ratification process, these laws should introduce to the legal system of Sri Lanka through acts passed by the parliament. Unfortunately, Sri Lanka adopt only the ICCPR act ${ }^{40}$ to domestic jurisdiction among the cardinal international human rights conventions. Therefore the CKDu affected individuals are unable to enjoy the major human rights concepts in international conventions which relates to CKDu even though Sri Lanka is a signatory to these documents.

So far, none of the cases arrives at court in the matter of human right violation of CKDu affected victims, therefore, the court incapable of getting an opportunity to interpret the domestic fundamental rights or apply international human rights law to domestic jurisdiction which addresses the CKDu.

But in the recent past a landmark judgment delivered by the California Court stating that the company who manufacture Glyphosate (Commercial Name -Round Up) which is major responsible agrochemical of CKDu in

37 Article 9 The States Parties to the present Covenant recognize the right of everyone to social security, including social insurance.

${ }^{38} \mathrm{https} / / /$ documents-dds-ny.un.org/doc/UNDOC/GEN/N09/479/35/PDF/N0947935.pdf?OpenElement

${ }^{39}$ Dualism in International Law-Treat the municipal law and international law are two distinct, self-contained systems which regulate different thighs.

${ }^{40}$ No 56 of 2007 
Sri Lanka ${ }^{41}$, should pay $\$ 289$ million as a compensation to a cancer patient for the damage was occurred due to the usage of this chemical. ${ }^{42}$

One of the main objects of this work was to analyze domestic and international jurisdiction and the researcher able to explore both domestic and international laws which relate to CKDu and its consequences. The domestic fundamental rights regime does not directly address the CKDu even though through the case law these rights were creatively interpreted in favour of the general public. The international law paves a sufficient path to directly address CKDu through its legal provisions other than domestic law. The international human rights law aims to protect the present and future generation form diseases like CKDu while introducing the right to access clean water. Unfortunately, the domestic justice system does not have a long-term action plan to safeguard its people from such type of major human rights violations.

It could understand that the international human rights regime is actively participating to protect mankind from man-made diseases like CKDu but unfortunately the domestic jurisdiction is in backwater to address CKDu.

Therefore the government of Sri Lanka should take immediate actions to follow the recommendations to protect the human rights of its citizens who are affected by CKDu.

Through the constitutional amendment the right to life, right to a healthy environment should expressly declare as fundamental rights of the citizens of Sri Lanka. Further, adopt the Resolution 64/292 to territorial jurisdiction to declare the water as a human right and should introduce it to as a fundamental right of Sri Lanka. The human rights activists and legal experts should guide and update the legislator in relation to contemporary developments in human rights of the global village. Further, they should be competent to adopt the rights which are appropriate to a multi-cultural society in Sri Lanka.

At present, a dialogue regarding a new constitution is becoming a popular topic in society. The Constitutional Reform Committee publish their recommendations regarding the new constitution. Therefore the present ruling party and legislature pay their attention to the report of Committee while introducing the new Constitution as the report contains crucial points which are enabled to radiate the human right regime in Sri Lankan context.

Further, the non-governmental and civil organizations of Sri Lanka have an inalienable responsibility to raise their voices to protect the fundamental rights of CKDu affected community. The organizations which are enthused the environmental issues and human rights should take legal actions against the violation of human rights behalf of CKDu affected victims and their families under the principle of public interest litigation.

Finally, the judiciary of Sri Lanka should apply appropriate human rights developments to the Sri Lankan context from the globe while interpreting the law and delivering judgments. Because they are the persons who could interpret the law in a creative manner in favour of mankind.

\section{Reference}

Al-Haj Ashik and Others v OIC Weligama Police and 8 others (2007) XIII Bar Association Law Journal Report, 159

Bandarage A., 2013, Political Economy of Epidemic Kidney Disease in Sri Lanka, SAGE Open OctoberDecember 2013: 1-13

\footnotetext{
${ }^{41}$ Jayasumana, C.at el (2013) P. Glyphosate, Hard Water and Nephrotoxic Metals: Are They the Culprits Behind the Epidemic of Chronic Kidney Disease of Unknown Aetiology in Sri Lanka?' International Journal of Environ Research and Public health. Feb; 11(2), pp. 2125-2147

${ }^{42}$ Tina Bellon,2018, Monsanto ordered to pay \$289 million in world's first Roundup cancer trial
} 
Bulankulame v The Secretary, Ministry of Industrial Development and Others, (Eppawela case), (2000) 3 SLR 243,

Chandrajith, R, Nanayakkara, S.I.K, Athuraliya, T.N.C, Dissanayake. T.N.C and Koizumi A, 2011, Mycotoxin Detection in Urine Samples from Patients with Chronic Kidney Disease of Uncertain Etiology in Sri Lanka, Bulletin of Environmental Contamination and Toxicology Vol 87, No 1, Pp6-10 •

Chandrajith, R., Seneviratna, S., Wickramaarachchi, K., Attanayake, T., Aturaliya, T. N. C., \& Dissanayake, C. B. (2010) 'Natural radionuclides and trace elements in rice field soils in relation to fertilizer application: Study of a chronic kidney disease area in Sri Lanka', Environmental Earth Sciences, 60, 193-201.

Constitution of Socialist Democratic Republic Sri Lanka,1978

Development Agenda, Afe Babalola University, Journal of Sustainable. Development. Law and Policy Vol. 9: 1: 2018 ,

Glyphosate Facts Transparency on Safety Aspects and use of Glyphosate containing herbicides in Europe , 2015, Glyphosate and Chronic Kidney Disease in Sri Lanka https://www.glyphosate.eu/glyphosate-and-chronickidney-disease-sri-lanka [Accessed on 24th September 2018]

Gunarathne C.,2015, Using Constitutional Provisions to advance Environmental Justice - Some reflections on Sri Lanka, Law Environment and Development Journal, Vol 11/2, P 72

Gunathilake S.K., Samaratunge S.S., Rubasinghe R.T.,2014, Chronic Kidney Disease (CKD) in Sri Lanka Current Research Evidence Justification: A Review, Sabaragamuwa University Journal Volume 13 Number 2; December 2014, pp 31-58

Handunnetti, D. \& Daniel, S. (2012) 'Conflicting reports highlight scientific data gaps in Sri Lanka's chronic kidney disease', SciDevNet. Richard L H, Human Rights and the Environment, Earth right International, 1997, p 1

International Covenant on Civil and Political Rights

International Covenant on Economic Social and Cultural Rights

Jayasinghe T. R.K.Y, 2011, Chronic Kidney Disease (Risk factor identification) (Secondary data analysis), Faculty of Agriculture, University of Peradeniya

Jayasumana, C., Gunatilake, S., and Senanayake,(2013)' P. Glyphosate, Hard Water and Nephrotoxic Metals: Are They the Culprits Behind the Epidemic of Chronic Kidney Disease of Unknown Etiology in Sri Lanka?' International Journal of Environ Research and Public Health. Feb; 11(2), pp. 2125-2147

Jayathilaka, N., Mendis, S., Maheepala, P., Firdosi, M., Chronic kidney diseases of uncertain aetiology ( CKDu) in Sri Lanka: Geographic Distribution and environmental implications', 2011, Environmental Geochemistry and Health, 33, pp.267-278

Juantey A.G., 2018, Reconciling Human Rights and the Environment: A Proposal to Integrate the Right to Food with Sustainable Development in 2030

Karim A., 2003, Environmental Protection, Public Health and Human Rights an Integrated Assessment, Science and Human Right Programme, American Association for Advancement of Science

Lunyera, J., Mohottige, D., Von, Isenburg, M.J., Patel, U.D. and Stanifer, J.W. (2015) ' CKD of Uncertain Etiology: A Systematic Review', CJASN ePress.

Ranasinghe .H, Ranasinghe M., 2015, Status, Gaps and Way Forward in Addressing the Chronic Kidney Disease Unidentified (CKDu) in Sri Lanka, Journal of Environmental Professionals Sri Lanka, 2015 - Vol. 4 No. 2 - 58-68

Ranasinghe M. S.,2017, Chronic Kidney Disease unidentified in Sri Lanka: Towards an Integrated Solution, York University, Ontario

Richard L H, Human Rights and the Environment, Earth right International,1997,p 1

Sri Lanka Medical Association, Chronic kidney disease of unknown aetiology in the North Central Province of Sri Lanka: trying to unravel the mystery, 2011, The Ceylon Medical Journal, Sri Lanka Medical Association, Volume 56, No.4,

Sriyani Silva V Iddamalgoda, Officer in Charge Police Station Paiyagala and Others (2003) 1 SLR 14 
Tina Bellon, 2018, Monsanto ordered to pay \$289 million in world's first Roundup cancer trial https://www.reuters.com/article/us-monsanto-cancer-lawsuit/monsanto-ordered-to-pay-289-million-in-worldsfirst-roundup-cancer-trial-idUSKBN1KV2HB[Accessed on 25 ${ }^{\text {th }}$ September 2018]

Universal Declaration of Human Rights

Valcke M., Levasseur M.E., Silva A.S D., Wesseling C.,2017, Pesticide exposures and chronic kidney disease of unknown aetiology: an epidemiologic review, Environmental Health 16:49

Wilson, C., 1998. "Cost and Policy Implications of Agricultural Pollution with special Reference to Pesticides". $\mathrm{PhD}$ Thesis, Department of economics, University of St Andrews, Scotland, U.K. 